\title{
KEDUDUKAN PERMENKUMHAM NOMOR 17 TAHUN 2018 DALAM MENJAMIN KEPASTIAN BERUSAHA PERSEKUTUAN KOMANDITER
}

\author{
THE POSITION OF THE MINISTER OF LAW AND HUMAN RIGHTS REGULATION \\ NUMBER 17 OF 2018 IN LIMITED PARTNERSHIPS OF BUSINESS CERTAINTY
}

\section{Mochammad Aznawi Faisal*, Sihabudin, Shinta Hadiyantina}

Program Studi Magister Kenotariatan

Fakultas Hukum Universitas Brawijaya

Jalan M.T. Haryono Nomor 169 Malang 65145, Indonesia

\section{INFO ARTIKEL}

\section{Riwayat Artikel: \\ Diterima : 25 Juni 2020 \\ Disetujui : 12 September 2021}

\section{Keywords:}

company registration, limited partnership, business certainty

\section{Kata Kunci:}

pendaftaran perusahaan, persekutuan komanditer, kepastian berusaha

\section{*) Korespondensi:}

E-mail: mochammadaznawi@ gmail.com

\begin{abstract}
: this study aimed to analyze changes in the provisions for registering limited partnership after enacting the Minister of Law and Human Rights Regulation Number 17 of 2018 and the position of Minister of Law and Human Rights Regulation Number 17 of 2018 on the hierarchy of laws and regulations in Indonesia. The type of research used was normative juridical law with a conceptual, historical, and statutory approach. After the enactment of Minister of Law and Human Rights Number 17 of 2018, the authority to register limited partnerships, which was previously the authority of the Minister of Trade, was transferred to the Minister of Law and Human Rights. The position of Minister of Law and Human Rights Regulation Number 17 of 2018 is seen from the procedure for forming ministerial regulations that do not meet the requirements as implementing regulations and are contrary to the principle of business certainty.
\end{abstract}

\begin{abstract}
Abstrak: kajian ini bertujuan untuk menganalisis perubahan ketentuan pendaftaran persekutuan komanditer setelah berlakunya Peraturan Menteri Hukum dan HAM (Permenkumham) Nomor 17 Tahun 2018 dan kedudukan Permenkumham Nomor 17 Tahun 2018 berdasarkan hierarki peraturan perundangundangan di Indonesia. Jenis penelitian yang digunakan adalah hukum yuridis normatif dengan pendekatan konseptual, pendekatan historis, dan pendekatan perundang-undangan. Setelah berlakunya Permenkumham Nomor 17 Tahun 2018, kewenangan dalam pendaftaran persekutuan komanditer yang sebelumnya menjadi kewenangan Menteri Perdagangan beralih kepada Menteri Hukum dan Hak Asasi Manusia. Kedudukan Permenkumham Nomor 17 Tahun 2018 dilihat dari tata cara pembentukan peraturan menteri belum memenuhi syarat sebagai peraturan pelaksana dan bertolak belakang dengan prinsip kepastian berusaha.
\end{abstract}

\section{PENDAHULUAN}

Persekutuan komanditer merupakan salah satu bentuk badan usaha. Pasal 19 Kitab Undang-Undang Hukum Dagang (KUHD) menjelaskan bahwa persekutuan komanditer merupakan perseroan untuk menjalankan suatu perusahaan. Persekutuan komanditer dibentuk oleh satu orang atau beberapa orang sekutu yang bertanggungjawab untuk seluruhnya pada satu pihak dan bertindak sebagai pelepas uang pada pihak lain (Safitri \& Mahartayasa, 2014). Persekutuan komanditer terdiri atas dua macam sekutu yaitu sekutu komplementer berperan sebagai pengurus persekutuan dan sekutu komanditer merupakan sekutu diam atau tidak bekerja (Nasution \& Kurniawan, 2019). Sekutu diam berperan memberikan pemasukannya dan tidak terlibat dalam pengurusan perusahaan.

Pendaftaran persekutuan komanditer pada awalnya diatur dalam Undang-Undang 
Nomor 3 Tahun 1982 tentang Wajib Daftar Perusahaan. Penyelenggaraan pendaftaran perusahaan sesuai dengan ketentuan undangundang tersebut diselenggarakan oleh Menteri Perdagangan. Permohonan pendaftaran perusahaan dapat dilakukan melalui kantor pendaftaran perusahaan yang telah ditentukan oleh Menteri. Setiap perusahaan memiliki kewajiban untuk mendaftarkan perusahaannya ke dalam daftar perusahaan (Nurhayati dkk., 2019). Pemilik atau pengurus perusahaan memiliki kewajiban untuk melakukan pendaftaran atau dapat diwakilkan oleh orang lain dengan memberikan surat kuasa.

Pejabat yang bertugas di kantor pendaftaran perusahaan, memiliki wewenang dalam menerima maupun menolak pendaftaran sesuai dengan ketentuan undang-undang. Pihak yang ditolak dapat mengajukan keberatan kepada Menteri, sedangkan pihak yang telah disahkan pendaftarannya akan diberikan tanda daftar perusahaan yang berlaku dalam jangka waktu 5 tahun sejak tanggal dikeluarkannya. Tujuan diselenggarakannya daftar perusahaan yaitu untuk mencatat bahan-bahan keterangan yang dibuat dengan benar oleh suatu perusahaan yang merupakan sumber informasi resmi bagi semua orang yang berkepentingan. Informasi resmi tersebut terdiri atas identitas, data, dan keterangan lain mengenai perusahaan yang tercantum dalam daftar perusahaan sebagai wujud jaminan kepastian berusaha (Pradana, Sihabudin, \& Puspitawati, 2019). Daftar perusahaan memberikan kemudahan dalam mengetahui perkembangan perusahaan di Indonesia.

Mekanisme pendaftaran perusahaan di Indonesia pun mengalami perubahan akibat kemajuan teknologi. Perkembangan teknologi informasi khususnya terkait teknologi internet sangat berpengaruh dalam sektor pelayanan perizinan berusaha. Perkembangan teknologi internet yang semakin pesat menimbulkan inovasi baru, sehingga pemerintah mengeluarkan Peraturan Pemerintah Nomor 24 Tahun 2018 tentang Pelayanan Perizinan Berusaha Secara Elektronik (Pradana, Sihabudin \& Puspitawati, 2019). Pasal 15 ayat (3) menjelaskan bahwa pendaftaran persekutuan komanditer diselenggarakan oleh Menteri Hukum dan Hak Asasi Manusia. Peralihan kewenangan dari Menteri Perdagangan kepada Menteri Hukum dan Hak Asasi Manusia mengakibatkan pendaftaran perusahaan dilakukan melalui sistem Online Single Submission (OSS).
Pelaku usaha juga melakukan pendaftaran melalui sistem OSS. Setelah mendaftar, pelaku usaha diberi bukti pendaftaran yaitu berupa Nomor Induk Berusaha (NIB). Bukti pendaftaran NIB merupakan pengesahan dari Tanda Daftar Perusahaan (TDP), Angka Pengenal Import (API), dan hak akses kepabeaan sebagai eksportir dan importir. Pemerintah melakukan terobosan dalam menunjang pertumbuhan investasi dalam era digital dengan mengeluarkan Peraturan Menteri Hukum dan Hak Asasi Manusia Republik Indonesia Nomor 17 Tahun 2018 tentang Pendaftaran Persekutuan Komanditer, Persekutuan Firma, dan Persekutuan Perdata. Permenkumham Nomor 17 Tahun 2018 merupakan peraturan pelaksana dari Peraturan Pemerintah Nomor 24 Tahun 2018 tentang Pelayanan Perizinan Berusaha Secara Elektronik (Maryoto, 2020). Berlakunya peraturan menteri tersebut diharapkan segala sesuatu terkait dengan pendaftaran perusahaan dapat dikerjakan dengan cepat, mudah dan efisien.

Kewenangan penyelenggaraan pendaftaran persekutuan komanditer sebagaimana yang dijelaskan dalam peraturan tersebut beralih kepada Menteri Hukum dan Hak Asasi Manusia. Kewenangan yang diatur di dalam peraturan perundang-undangan dilaksanakan sendiri oleh pejabat atau badan yang tertera di peraturan dasarnya (Gandara, 2020). Permohonan pendaftaran persekutuan komanditer sesuai peraturan ini dilakukan melalui Sistem Administrasi Badan Usaha (SABU) secara elektronik. Notaris sebagaimana dijelaskan dalam Permenkumham Nomor 17 Tahun 2018, berwenang untuk membantu pelaku usaha dalam melakukan pendaftaran perusahaan melalui SABU, mencetak Surat Keterangan Terdaftar (SKT) dengan membubuhkan tanda tangan dan cap stempel jabatan, serta membuat frasa pernyataan bahwa SKT tersebut dicetak melalui SABU. Peraturan tersebut juga menjelaskan bahwa pencatatan perusahaan yang dahulu terdapat pada pengadilan negeri dalam jangka waktu satu tahun, maka wajib melakukan pencatatan pendaftaran sesuai dengan ketentuan peralihan yang baru. Pencatatan pendaftaran diperbolehkan menggunakan nama yang telah dipakai secara sah oleh CV, firma, persekutuan perdata yang telah terdaftar melalui SABU.

Penataan sistem atau regulasi dalam pelayanan perizinan sesuai dengan penjelasan di atas, mengakibatkan adanya perubahan 
kewenangan dalam penyelenggaraan pendaftaran persekutuan komanditer. Namun, penjelasan peralihan kewenangan penyelenggaraan pendaftaran persekutuan komanditer dari Menteri bidang Perdagangan kepada Menteri Hukum dan Hak Asasi Manusia tidak dijelaskan dalam Permenkumham Nomor 17 Tahun 2018. Dengan demikian, berlakunya peraturan tersebut masih belum memenuhi asas kepastian hukum (Julyano \& Sulistyawan, 2019). Berdasarkan permasalahan tersebut, kajian ini akan membahas mengenai (1) perubahan kewenangan dalam pendaftaran persekutuan komanditer dan (2) kedudukan Permenkumham Nomor 17 Tahun 2018 menurut hierarki peraturan perundangundangan di Indonesia.

\section{METODE}

Jenis penelitian dalam kajian ini adalah yuridis normatif (normatif legal research), dengan fokus mengkaji penerapan kaidahkaidah atau norma-norma dalam hukum positif. Pendekatan yang digunakan yaitu pendekatan konseptual, pendekatan historis, dan pendekatan undang-undang. Undang-undang yang dijadikan sebagai fokus telaah dalam kajian ini yaitu Permenkumham Nomor 17 Tahun 2018 tentang Pendaftaran Persekutuan Komanditer, Persekutuan Firma dan Persekutuan Perdata. Sumber data yang dikumpulkan terdiri atas data primer, data sekunder, dan data tersier. Ketiga bahan tersebut dikumpulkan melalui studi dokumenter. Studi dokumenter adalah studi yang digunakan untuk mengkaji berbagai dokumen-dokumen terkait peraturan perundang-undangan serta dokumendokumen yang sudah ada.

\section{HASIL DAN PEMBAHASAN}

\section{Perubahan Kewenangan Penyelenggaraan Pendaftaran Persekutuan Komanditer setelah Berlakunya Permenkumham Nomor 17 Tahun 2018}

Hukum digunakan sebagai alat rekayasa sosial atau law as a tool of social engineering (Kusumaatmadja, 2002). Hukum dagang merupakan salah satu penunjang keberhasilan pembangunan ekonomi nasional. Hukum dagang merupakan salah satu cabang hukum yang berkaitan dengan kegiatan bisnis. Hukum dagang tidak hanya dipelajari melalui KUHD (Atmadjaja, 2012). Hukum dagang pada saat ini berkembang secara dinamis sehingga diperlukan pemahaman secara umum agar dapat memahami tentang prinsip-prinsip substansi dan peranan hukum dagang di Indonesia. Fungsi hukum dagang yaitu sebagai sarana dalam memberikan fasilitas terhadap kegiatan bisnis. Kelancaran kegiatan bisnis juga diawali dengan adanya kesepakatan yang tertuang di dalam perjanjian antar mitra usaha (Ardiansyah, Hamidah, \& Mochtar, 2019). Hukum dagang difungsikan sebagai pranata dari suatu kegiatan bisnis dan tidak lepas dari peran pemerintah dalam menciptakan situasi bisnis yang mendukung pembangunan.

Indonesia, dalam merencanakan, melaksanakan dan mengevaluasi pembangunan ekonomi membutuhkan piranti hukum sebagai landasan kegiatan dan menjamin kegiatan usaha. Perusahaan (Bedriff) berasal dari istilah ekonomi. Kitab UndangUndang Hukum Dagang sering menggunakan istilah perusahaan, sehingga seseorang yang memiliki perusahaan disebut dengan pengusaha. Secara spesifik KUHD belum menjelaskan tentang pengertian perusahaan. Pengertian perusahaan dijelaskan dalam Pasal 1 Hurufb Undang-Undang Nomor 3 Tahun 1982 tentang Wajib Daftar Perusahaan bahwa perusahaan adalah setiap bentuk usaha yang bersifat tetap dan terus menerus serta didirikan dalam wilayah Negara Republik Indonesia yang bertujuan untuk memperoleh keuntungan atau laba. Perusahaan merupakan fasilitas bagi pengusaha untuk dapat memperoleh keuntungan atau laba dalam menjalankan kegiatan usahanya (Muhammad, 2010). Pengusaha dalam mencapai keuntungan tersebut harus merancang strategi bisnis melalui kebijakan yang tepat, sehingga mampu menentukan arah perusahaannya.

Pranata dalam menjalankan suatu perusahaan terkandung di dalam hukum perusahaan. Hukum perusahaan berada dalam ruang lingkup hukum perdata (hukum dagang) serta sebagian juga mencakup hukum administrasi negara yang tercermin kepada peraturan perundang-undangan di luar Kitab Undang-Undang Hukum Perdata dan KUHD. Hukum perusahaan jika dilihat dari segi objek usaha dan tata perniagaan, termasuk dalam lingkup hukum perdata yang secara khusus di bidang hukum harta kekayaan yang di dalamnya terletak hukum dagang. Berbeda jika dilihat dari segi kegiatan usahanya yang bergerak pada sektor kegiatan ekonomi, maka hukum perusahaan termasuk dalam cakupan hukum ekonomi. Kedudukan hukum perusahaan terdapat pada cakupan hukum dagang (termasuk 
hukum perdata), hukum administrasi negara, dan hukum ekonomi. Hukum perusahaan memiliki tiga aspek sekaligus yaitu ekonomi perusahaan, hukum dagang atau perdata (privat), dan hukum administrasi negara atau publik (Mulhadi, 2010). Hukum perusahaan terletak dalam hukum privat serta hukum publik dan hukum ekonomi.

Bentuk perusahaan atau badan usaha (business organization) di Indonesia memiliki beraneka ragam jika ditinjau dari segi hukum maupun secara teoritis (Mulhadi, 2010). Bentuk badan usaha di Indonesia sebenarnya mengikuti bentuk usaha dari Belanda antara lain perseorangan atau persekutuan dagang, persekutuan komanditer, firma, persekutuan perdata perseroan terbatas, yayasan, dan koperasi (Utami, 2020). Bentuk usaha dapat diketahui dengan jelas sesuai yang tertera dalam akta pendirian perusahaan. Akta pendirian di dalamnya memuat tentang anggaran dasar dari perusahaan tersebut serta setiap perusahaan yang menjalankan kegiatan usahanya wajib memenuhi syarat operasional sebagai perusahaan (Muhammad, 2010). Perusahaan yang telah memenuhi persyaratan tersebut maka dinyatakan memiliki bukti legalitas kegiatan usaha. Bukti legalitas sebagaimana disebutkan sebelumnya terdiri atas Tanda Daftar Usaha Perdagangan (TDUP) dan Surat Izin Usaha Perdagangan (SIUP).

Pengusaha memiliki kewajiban untuk mendaftarkan perusahaan dengan jangka waktu tiga bulan setelah perusahaan menjalankan kegiatan usahanya sesuai dengan Pasal 10 UndangUndang Nomor 3 Tahun 1982 tentang Wajib Daftar Perusahaan. Jangka waktu pendaftaran terhitung sejak perusahaan tersebut memiliki SIUP (Nurhayati dkk., 2019). Setiap perusahaan sebelum melakukan suatu kegiatan usaha lebih baik melakukan pendaftaran perusahaan terlebih dahulu, karena hal ini sangat mendukung operasional suatu kegiatan usaha (Yanti, 2017). Perusahaan harus memiliki SIUP sebelum melakukan kegiatan usahanya (Atmadjaja, 2012). Tujuan diadakannya daftar perusahaan dijelaskan dalam Pasal 2 Undang-Undang Nomor 3 Tahun 1982 yaitu mencatat bahan-bahan keterangan yang dibuat secara benar dari suatu perusahaan dan sebagai sumber informasi resmi untuk semua pihak yang berkepentingan mengenai identitas, data, serta keterangan lainnya tentang perusahaan dalam rangka menjamin kepastian berusaha.
Daftar perusahaan bertujuan untuk mencegah adanya perusahaan yang tidak bertanggung jawab, menghindari adanya persaingan secara tidak sehat pada suatu perusahaan, dan memudahkan mengetahui perkembangan perusahaan di Indonesia. Pendaftaran perusahaan juga memberikan kemudahan bagi pemerintah dalam pembinaan, pengarahan, pengawasan, serta menciptakan lingkungan yang sehat dalam dunia usaha sehingga menjamin perkembangan usaha dan kepastian berusaha (Muhammad, 2010). Bagi pengusaha yang mengurus legalitas perusahaannya dapat memudahkan kegiatan usahanya serta memudahkan dalam mengembangkan usahanya menuju ke arah yang lebih baik (Fitriani, 2017). Legalitas suatu perusahaan menjadi unsur yang terpenting untuk mengesahkan suatu badan usaha sehingga dilindungi oleh hukum dan diakui oleh masyarakat.

Daftar perusahaan yang dijelaskan dalam Undang-Undang Nomor 3 Tahun 1982 tentang Wajib Daftar Perusahaan diselenggarakan oleh Menteri bidang Perdagangan dengan memenuhi persyaratan-persyaratan sebagaimana yang telah ditentukan dalam melakukan daftar perusahaan. Persyaratan yang sudah terpenuhi diserahkan kepada kantor pendaftaran perusahaan yang telah ditunjuk oleh Menteri bidang perdagangan. Pejabat yang berwenang pada kantor pendaftaran perusahaan juga diberikan kewenangan dalam menolak atau mengesahkan adanya daftar perusahaan tersebut. Perusahaan yang telah memenuhi persyaratan dapat diberikan Tanda Daftar Perusahaan (TDP) sebagai legalitas usahanya. Pelayanan perizinan berusaha secara elektronik ini dilakukan melalui sistem Online Single Submission (OSS).

Kewenangan penyelenggaraan pendaftaran perusahaan sebelum berlakunya Permenkumham Nomor 17 Tahun 2018, dimiliki oleh menteri bidang perdagangan. Kewenangan berdasarkan sumber didapatkannya terbagi menjadi tiga, yaitu kewenangan atribusi, delegasi, dan mandat (Gandara, 2020). Kewenangan atribusi adalah kewenangan pembagian kekuasaan yang diberikan secara langsung oleh undang-undang. Kewenangan delegasi merupakan kewenangan yang bersumber dari pelimpahan organ pemerintah yang bersumber pada peraturan perundangundangan. Kewenangan mandat kewenangan yang bersumber dari prosedur pelimpahan dari pejabat atau badan yang lebih tinggi ke yang 
lebih rendah. Perubahan kewenangan dalam pendaftaran persekutuan komanditer setelah berlakunya Permenkumham Nomor 17 Tahun 2018, seharusnya termasuk dalam kategori kewenangan delegatif bukan atributif.

Permenkumham tersebut juga tidak menjelaskan adanya peralihan kewenangan dari Menteri bidang Perdagangan kepada Menteri Hukum dan Hak Asasi Manusia sehingga kewenangan yang didapatkan oleh Menteri Hukum dan Hak Asasi Manusia merupakan kewenangan atribut. Terjadi adanya dua organ pemerintah yang memiliki kewenangan dalam penyelenggaraan pendaftaran persekutuan komanditer. Kewenangan dalam menyelenggarakan pendaftaran persekutuan komanditer yang diselenggarakan oleh dua organ pemerintah ini bertolak belakang dengan tujuan dari daftar perusahaan itu sendiri. Tujuan daftar perusahaan yaitu sebagai sumber informasi resmi untuk semua pihak yang berkepentingan mengenai identitas, data, serta keterangan lainnya tentang perusahaan yang digunakan untuk menjamin kepastian berusaha.

Kedudukan Permenkumham Nomor 17 Tahun 2018 dalam Menjamin Kepastian Berusaha pada Penyelenggaraan Pendaftaran Persekutuan Komanditer berdasarkan Hierarki Perundang-Undangan di Indonesia

Konsep undang-undang berasal dari bahasa Belanda yaitu wet. Pengertian mengenai undangundang dalam kepustakaan hukum Belanda terbagi menjadi dua yaitu dalam arti formil dan dalam arti materiel. Undang-undang dalam arti formil merupakan suatu hal yang lazim dengan sebutan undang-undang saja atau Wet Formele Zin, sedangkan dalam artian materiel merupakan segala bentuk dari peraturan perundang-undangan tersebut atau wet in materiele zin (Attamimi, 1990). Pembentukan norma hukum pada dasarnya adalah hukum mengatur pembentukannya karena norma hukum yang satu menentukan norma hukum yang lainnya hingga derajat tertentu menentukan juga derajat lainnya (Kelsen, 2007). Suatu norma hukum yang memiliki derajat lebih tinggi menentukan pembentukan norma hukum yang derajatnya lebih rendah.

Pembentukan peraturan perundang-undangan secara umum mengatur dan menata kehidupan dalam suatu negara agar masyarakat yang diatur oleh hukum memperoleh kepastian, kemanfaatan, keadilan dalam kehidupan bernegara dan bermasyarakat (Jalaluddin, 2011).
Pembentukan peraturan perundang-undangan di Indonesia diatur dalam Undang-Undang Nomor 12 Tahun 2011 tentang Pembentukan Peraturan Perundang-Undangan. Peraturan perundangundangan berdasarkan penjelasan undang-undang tersebut, merupakan suatu peraturan tertulis yang memuat norma hukum yang mengikat untuk umum dengan cara pembuatannya mencakup tahapan perencanaan, penyusunan, pembahasan, pengesahan atau penetapan dan pengundangan. Peraturan perundang-undangan juga dibentuk atau ditetapkan oleh lembaga negara atau pejabat yang berwenang dengan cara melalui tahapan prosedur yang ditentukan.

Pembentukan peraturan perundang-undangan dijelaskan dalam Pasal 5 Undang-Undang Nomor 12 Tahun 2011 bahwa peraturan perundangundangan dibentuk harus berdasarkan pada asas pembentukannya yaitu (a) kejelasan tujuan, (b) kelembagaan atau pejabat pembentuk yang tepat, (c) kesesuaian antara jenis, hierarki, dan materi muatan, (d) dapat dilaksanakan, (e) kedayagunaan dan kehasilgunaan, (f) kejelasan rumusan, serta (g) keterbukaan. Pasal 6 angka (1) Undang -Undang Nomor 12 Tahun 2011 juga menjelaskan mengenai materi muatan peraturan perundang-undangan haruslah mencerminkan asas-asas yang telah diatur yaitu (a) pengayoman, (b) kemanusiaan, (c) kebangsaan, (d) kekeluargaan, (e) kenusantaraan, (f) Bhinneka Tunggal Ika, (g) keadilan, (h) kesamaan kedudukan dalam hukum dan pemerintahan, (i) ketertiban dan kepastian hukum, serta (j) keseimbangan, keserasian, dan keselarasan.

Pembentukan peraturan perundang-undangan juga dapat berisikan asas lain sesuai dengan bidang hukum peraturan perundang-undangan sebagaimana dijelaskan dalam Pasal 6 ayat (2). Kekuatan hukum peraturan perundang-undangan disusun berdasarkan jenis dan hierarki peraturan perundang-undangan yaitu (1) Undang-Undang Dasar Negara Republik Indonesia Tahun 1945, (2) Ketetapan Majelis Permusyawaratan Rakyat, (3) Undang-Undang atau Peraturan Pemerintah Pengganti Undang-Undang, (4) Peraturan Pemerintah, (5) Peraturan Presiden, (6) Peraturan Daerah Provinsi, dan (7) Peraturan Daerah Kabupaten atau Kota.

Kekuatan hukum peraturan perundangundangan selain dalam jenis dan hierarki meliputi peraturan yang ditetapkan oleh Majelis Permusyawaratan Rakyat (MPR), 
Dewan Perwakilan Rakyat (DPR), Dewan Perwakilan Daerah (DPD), Mahkamah Agung (MA), Mahkamah Konstitusi (MK), Badan Pemeriksa Keuangan (BPK), Komisi Yudisial (KY), Bank Indonesia, Menteri, badan, lembaga, atau komisi yang setingkat yang dibentuk dengan undang-undang atau Pemerintah atas perintah undang-undang, Dewan Perwakilan Rakyat Daerah Provinsi, Gubernur, Dewan Perwakilan Rakyat Daerah Kabupaten atau Kota, Bupati atau Walikota, Kepala Desa atau yang setingkat. Peraturan perundang-undangan yang ditetapkan dapat diakui keberadaannya serta memiliki kekuatan hukum yang mengikat jika pembentukannya diperintahkan oleh peraturan perundang-undangan yang lebih tinggi serta dibentuk berdasarkan kewenangan.

Kedudukan pembentukan peraturan menteri sebagaimana dijelaskan dalam Undang-Undang Nomor 12 Tahun 2011 termasuk dalam peraturan lainnya meskipun tidak secara spesifik masuk dalam hierarki peraturan perundang-undangan, akan tetapi kedudukannya tetap diakui (Aditya \& Winata, 2018). Permenkumham Nomor 17 Tahun 2018 merupakan peraturan pelaksanaan dari Peraturan Pemerintah Nomor 24 tahun 2018 tentang Pelayanan Perizinan Berusaha Terintegrasi Secara Elektronik. Pemberian delegasi pembuatan peraturan pelaksanaan kepada eksekutif mengandung risiko kurangnya pengawasan, publikasi dan diseminasi yang berpotensi menyimpangi, memperluas, atau mempersempit materi undang-undang (Maryoto, 2020). Kementerian atau lembaga cenderung menginginkan kewenangan yang besar sehingga Permenkumham bisa memiliki kelemahan sebagai peraturan pelaksana dari aturan perundangan sebelumnya.

Pembangunan hukum nasional yang semakin berkembang, membutuhkan perbaikan dan mekanisme yang tepat dalam memperkuat pembentukan peraturan perundang-undangan yang berkelanjutan. Pemerintah melakukan perubahan berupa Undang-Undang Nomor 15 Tahun 2019 tentang Perubahan Atas UndangUndang Nomor 12 Tahun 2011 tentang Pembentukan Peraturan Perundang-Undangan. Perubahan tersebut dilakukan karena UndangUndang Nomor 12 Tahun 2011 masih terdapat kekurangan serta belum mampu untuk menampung kebutuhan masyarakat sehingga perlu diadakan perubahan. Tujuan dari perubahan tersebut yaitu untuk mengetahui pencapaian hasil yang telah direncanakan, dampak yang ditimbulkan, dan manfaat bagi Negara Kesatuan Republik Indonesia atas pelaksanaan undang-undang sehingga perlu dilakukan pemantauan dan peninjauan.

Pemantauan dan peninjauan dilakukan dengan cara mengamati, mencatat, menilai dari pelaksanaan undang-undang. Pemantauan dan peninjauan dilaksanakan oleh DPR, DPD, dan Pemerintah dengan cara dikoordinasikan oleh DPR melalui alat khusus menangani di bidang legislasi. Hasil dari pemantauan dan peninjauan tersebut dapat menjadi usul dalam penyusunan Program Legislasi Nasional (Prolegnas). Pemantauan dan peninjauan terhadap undangundang dilakukan dalam tiga tahap, terdiri atas (1) tahap perencanaan, (2) tahap pelaksanaan, dan (3) tahap tindak lanjut. Pemantauan dan peninjauan undang-undang diatur masing-masing dengan peraturan DPR, DPD, dan Peraturan Presiden (Perpres). Kementerian atau lembaga yang menyelenggarakan urusan pemerintahan di bidang pembentukan peraturan perundangundangan tetap dilaksanakan oleh menteri yang bertugas dan berfungsi di bidang hukum.

Pembentukan peraturan pelaksana sesuai dengan penjelasan Undang-Undang Nomor 15 Tahun 2019 jika dikaitkan dengan Permenkumham Nomor 17 Tahun 2018 maka bisa dilihat bahwa Menteri memiliki kewenangan dalam mengeluarkan peraturan yang secara umum disebut dengan peraturan menteri. Persyaratan yang pertama memang sudah terpenuhi, akan tetapi karena Permenkumham Nomor 17 Tahun 2018 mengatur mengenai penyelenggaraan pendaftaran perusahaan berbentuk persekutuan komanditer maka seharusnya peraturan ini merujuk pada peraturan yang kedudukannya lebih tinggi yaitu Undang-Undang Nomor 3 Tahun 1982 tentang Wajib Daftar Perusahaan. Hal ini bertujuan agar pengaturannya dapat selaras dengan peraturan yang kedudukannya lebih tinggi. Penjelasan yang merujuk pada Undang-Undang Nomor 3 Tahun 1982 tidak ditemukan dalam Permenkumham Nomor 17 Tahun 2018, dengan demikian Permenkumham Nomor 17 Tahun 2018 belum memenuhi syarat pembentukan peraturan pelaksana.

Teori kepastian hukum dari Gustav Radbruch menjelaskan bahwa hukum diciptakan atau dibuat memiliki suatu tujuan (Julyano \& Sulistyawan, 
2019). Tujuan memiliki pengertian suatu nilai yang ingin diwujudkan oleh manusia. Hukum diciptakan dalam memenuhi tujuan yaitu keadilan untuk keseimbangan, kepastian untuk ketetapan, kemanfaatan untuk kebahagiaan pemikiran (Erwin, 2011). Tujuan hukum adalah untuk memajukan setiap warga negara dan bukan memaksakan perintah Tuhan atau melindungi hak-hak kodrat (Bentham, 2010). Jeremy Bentham juga mengemukakan bahwa kepastian merupakan salah satu unsur yang memastikan bahwa kesenangan itu akan terjadi (Robinson \& Garratt, 1998). Manusia berdasarkan kodrat hukum dan moralitas yang ilmiah, akan menghindari ketidaksenangan dan mencari kesenangan.

Berdasarkan pendapat kedua ahli ilmu hukum Gustav Radbuch dan Jeremy Bentham, dapat disimpulkan bahwa suatu hukum dibentuk dengan berdasarkan tujuan. Diharapkan dengan terbentuknya hukum, maka timbul suatu kepastian yang berdampak pada semua orang yang menjalankan hukum tersebut. Tujuan terbentuknya hukum jika diselaraskan dengan pembentukan peraturan perundang-undangan maka dalam pembentukannya haruslah memiliki tujuan sebagai kepastian serta menimbulkan kebahagian kepada setiap lapisan masyarakat yang menjalankanya. Kesimpulan kedua ahli hukum diatas jika dikaitkan dengan pembentukan Permenkumham Nomor 17 Tahun 2018 dirasa memang belum memenuhi tujuan dibentuknya suatu hukum, karena pembentukannya yang belum memenuhi syarat sebagai peraturan pelaksana. Hal yang ditimbulkan yaitu kedudukan peraturan perundang-undangan tersebut belum dapat diakui keberadaanya serta belum memiliki kekuatan hukum yang mengikat, sehingga bertolak belakang dengan tujuan awal dibentuknya suatu hukum.

\section{SIMPULAN}

Perubahan kewenangan penyelenggaraan pendaftaran persekutuan komanditer yang sebelumnya merupakan kewenangan Menteri Perdagangan beralih kepada Menteri Hukum dan Hak Asasi Manusia setelah berlakunya Permenkumham Nomor 17 Tahun 2018. Akan tetapi, dalam perubahan tersebut tidak ditemukan adanya peralihan kewenangan delegatif. Dengan demikian, kewenangan yang diterima kedua organ pemerintahan tersebut merupakan kewenangan atributif. Hal ini bertolak belakang dengan tujuan daftar perusahaan sebagai kepastian hukum karena menimbulkan adanya dua organ pemerintah yang memiliki kewenangan dalam penyelenggaraan pendaftaran persekutuan komanditer. Peralihan kewenangan perlu dijelaskan pada pengaturan Permenkumham Nomor 17 Tahun 2018 agar tidak menyebabkan adanya dua organ pemerintahan yang memiliki kewenangan sehingga dapat sesuai dengan tujuan diselenggarakannya daftar perusahaan. Kedudukan Permenkumham Nomor 17 Tahun 2018 sebagai peraturan pelaksana belum dapat diakui serta belum mempunyai kekuatan yang mengikat karena dalam pembentukannya tidak merujuk dari peraturan yang sebelumnya mengenai pendaftaran persekutuan komanditer. Pemantauan dan peninjauan terhadap pembentukan Permenkumham Nomor 17 Tahun 2018 perlu dilakukan agar pembentukannya dapat memenuhi syarat sebagai peraturan pelaksana sehingga kedudukannya dapat diakui dan mempunyai kekuatan hukum yang mengikat sesuai dengan peraturan tentang pembentukan peraturan perundang-undangan yang berlaku di Indonesia.

\section{DAFTAR RUJUKAN}

Aditya, Z. F., \& Winata, R. (2018). Rekonstruksi Hierarki Peraturan Perundang-Undangan di Indonesia, Jurnal Negara Hukum, 9(1), 79-100.

Ardiansyah, M., Hamidah, S., \& Mochtar, D. A. (2019). Perwujudan Asas Keadilan dan Keseimbangan dalam Pembuatan Akta Persekutuan Komanditer berdasarkan Akad Mudharabah. Jurnal Ilmiah Pendidikan Pancasila dan Kewarganegaraan, 4(2), 321-327.

Atmadjaja, D. I. (2012). Hukum Dagang Indonesia. Malang: Setara Press.

Attamimi, H. S. (1990). Peranan Keputusan Presiden Republik Indonesia dalam Penyelenggaraan Pemerintahan Negara. Jakarta: Universitas Indonesia.

Bentham, J. (2010). Teori Perundang-Undangan. Bandung: Nuansa \& Nusamedia

Erwin, M. (2011). Filsafat Hukum: Refleksi Krisis terhadap Hukum. Jakarta: PT. Raja Grafindo Persada.

Fitriani, R. (2017). Aspek Hukum Legalitas Perusahaan atau Badan Usaha dalam Kegiatan Bisnis. Jurnal Hukum Samudra Keadilan, 12(1), 136-145. 
Gandara, M. (2020). Kewenangan Atribusi, Delegasi dan Mandat. Jurnal Khazanah Hukum, 2(3), 92-99.

Jalaludin. (2011). Hakikat Fungsi Peraturan Perundang-Undangan sebagai Batu Uji Kritis terhadap Gagasan Pembentukan Perda yang Baik, Jurnal Ilmiah Universitas Tadulako, 6(3), 1-19.

Julyano, M., \& Sulistyawan, A. Y. (2019). Pemahaman terhadap Asas Kepastian Hukum melalui Konstruksi Penalaran Positivisme Hukum. Jurnal Crepido, 01(01), 13-22.

Kelsen, H. (2007). Teori Hukum dan Negara, Dasar-Dasar Ilmu Hukum Normatif sebagai Ilmu Hukum Deskriptif-Empirik, Alih Bahasa Drs. H. Soemardi. Jakarta: BEE Media Indonesia.

Kusumaatmadja, M. (2002). Konsep-Konsep Hukum dalam Pembangunan. Bandung: Penerbit Alumni.

Maryoto, J. (2020). Pendaftaran Persekutuan Komanditer Pasca Berlakunya Peraturan Menteri Hukum dan Hak Asasi Manusia Republik Indonesia Nomor 17 tahun 2018. Jurnal Elektronik Hukum Bisnis, 4(2), 485-498.

Muhammad, A. (2010). Hukum Perusahaan Indonesia. Bandung: PT. Citra Aditya Bakti.

Mulhadi. (2010). Hukum Perusahaan (BentukBentuk Badan Usaha di Indonesia). Ciawi: Ghalia Indonesia.

Nasution, K., \& Kurniawan, A. (2019). Pendaftaran Comamanditaire Vennotschap (CV) setelah Terbitnya Permenkumham Nomor 17 Tahun 2018. Jurnal Hasil Penelitian LPPM Universitas 17 Agustus Surabaya, 4(01), 50-68.

Nurhayati, I., Putri, K. D., Antoni, V., Sulistiowati, \& Pramono, N. (2019). Pendaftaran Badan Usaha secara Elektronik Pasca Diterbitkannya Peraturan Pemerintah Nomor 24 Tahun 2018. Jurnal Negara Hukum, 10(2), 167-189.

Pradana, I. N. A., Sihabudin, \& Puspitawati, D. (2019). Implikasi Hukum Penggunaan Data Pribadi Pihak Ketiga terhadap Keabsahan Perjanjian Pinjam Meminjam Uang Berbasis Teknologi Informasi. Jurnal Ilmiah Pendidikan Pancasila dan Kewarganegaraan, 4(2), 341-351.

Republik Indonesia. (1982). Undang-Undang Nomor 3 Tahun 1982 tentang Wajib Daftar
Perusahaan. Lembaran Negara Republik Indonesia Tahun 1982 Nomor 7. Tambahan Lembaran Negara Republik Indonesia Nomor 3214.

Republik Indonesia. (2011). Undang-Undang Nomor 12 Tahun 2011 tentang Pembentukan Peraturan Perundang-Undangan. Lembaran Negara Republik Indonesia Tahun 2011 Nomor 82. Tambahan Lembaran Negara Republik Indonesia Nomor 5234.

Republik Indonesia. (2018). Peraturan Pemerintah Nomor 24 Tahun 2018 tentang Pelayanan

Perizinan Berusaha Secara Elektronik. Lembaran Negara Republik Indonesia Tahun 2018 Nomor 90. Tambahan Lembaran Negara Republik Indonesia Nomor 6215. Republik Indonesia. (2018). Peraturan Menteri Hukum dan Hak Asasi Manusia Nomor 17 Tahun 2018 tentang Pendaftaran Persekutuan Komanditer, Persekutuan Firma, dan Persekutuan Perdata. Berita Negara Republik Indonesia Tahun 2018 Nomor 1011.

Republik Indonesia. (2019). Undang-Undang Nomor 15 Tahun 2019 tentang Perubahan atas Undang-Undang Nomor 12 Tahun 2011 tentang Pembentukan Peraturan Perundang-Undangan. Lembaran Negara Republik Indonesia Tahun 2019 Nomor 183. Tambahan Lembaran Negara Republik Indonesia Nomor 6398.

Robinson, D., \& Garratt, C. (1998). Mengenal Etika for Beginner. Bandung: Mizan.

Safitri, N. D., \& Mahartayasa, M. (2014). Pertanggungjawaban Sekutu dalam Persekutuan Komanditer yang Mengalami Kepailitan. Bali: Fakultas Hukum Bisnis Universitas Udayana.

Suhayati M. (2018). Permasalahan Perizinan Berusaha Terintegrasi secara Elektronik (Online Single Submission). Jakarta: Pusat Penelitian Badan Keahlian DPR RI.

Utami, P. D. Y. (2020). Pengaturan Pendaftaran Badan Usaha Bukan Badan Hukum melalui Sistem Administrasi Badan Usaha. Bali: Fakultas Hukum Universitas Udayana.

Yanti, Y. (2017). Tinjauan Yuridis terhadap Pelaksanaan Pendaftaran Perusahaan berdasarkan Undang-Undang Nomor 3 Tahun 1982 tentang Wajib Daftar Perusahaan (Studi Kota Mataram). Mataram: Fakultas Hukum Universitas Mataram. 